\title{
AZ ÉLET ÉRTELME A TÜNDÉRMESÉKBEN
}

\section{THE MEANING OF LIFE IN FAIRY TALES}

\author{
Bárdos József ${ }^{1 *}$ \\ 1 Pedagógusképző Kar, Neumann János Egyetem \\ https://doi.org/10.47833/2020.3.ART.003
}

\section{Kulcsszavak \\ tündérmese \\ mesemozzanat \\ metafora}

\section{Keywords:}

fairy tale

phase of fairy tale

metaphor

\section{Cikktörténet:}

Beérkezett 2020. május 10.

Átdolgozva 2020. július 14.

Elfogadva 2020. július 16.

\begin{abstract}
Összefoglalás
Ha megkíséreljük megmondani, mi az ember életének értelme, rájöhetünk, hogy ezt csak egy külső nézőpontból ítélhetnénk meg. A tündérmesék biztosithatnak számunkra ilyen nézőpontot annak felismeréséhez, mi az élet célja. Üzeneteiket elsősorban azok a mesemozzanatok közvetítik a maguk metaforikus módján, amelyekböl a klasszikus tündérmesék felépülnek. A legföbb üzenet, hogy sorsunkat ne csak átéljük, de teljes intenzitással meg is éljük, választásainkkal, döntéseinkkel találjuk meg a saját utunkat, amely elvezet bennünket ahhoz, hogy felnőtt, a világot megismerni akaró, a boldogságot kereső emberré váljunk.
\end{abstract}

Abstract
If we try to find the meaning of life, we need an external viewpoint.
Fairy tales can provide us some points of reference to recognize,
what is the purpose of our lives. We can find philosophical
messages in phases of classical fairy tales (in a metaphoric way).
The most important message is: we must not only live our lives
but live with full intensity, with our own choses and decisions. It
help us be a grown-up, creative individual who continously try to
find happiness.

\section{Bevezetés}

A XX. század kegyetlen tapasztalatai után a XXI. század embere a korábbinál sokkal erösebben kérdez rá az emberi élet értékére, értelmére, céljára. Tesszük ezt talán éppen azért, mert elvesztettük azokat a válaszokat, amelyek így vagy úgy, de eltakarták elölünk az ember parányi és jelentéktelen voltát a hallgatag univerzumban.

Hankiss Elemér így ír erröl: „Civilizációnk az élet értelmének, a szabadságnak, az emberiség fontosságának és halhatatlanságának káprázatos tüzijátéka. Ámítás és önámítás, de segít nekünk élni egy olyan univerzumban, melyben lehetséges, hogy nincs értelem, nincs szabadság és az ember számára nincs halhatatlanság." [1]

Ám minél inkább keressük a választ a kérdésre, mi az ember életének értelme, annál egyértelmübbé válik, hogy ezt csak egy külső nézőpontból ítélhetnénk meg. Szerencsére velünk élő kulturális örökségünk, (európai) műveltségünk részei, a klasszikus tündérmesék biztosíthatnak számunkra ilyen nézőpontot. Üzeneteiket azok a mesemozzanatok közvetítik, elsősorban metaforikusan, amelyekböl a mese felépül. A következőkben a tündérmese szerkezetét vizsgálva mutatom be, miként vihet közelebb ezek olvasása, tanulmányozása a nagy kérdésre adandó válasz legalább egy részének megtalálásához.

\footnotetext{
* dr. Bárdos József, tel.: +36 30523 6385, E-mail cím: bardos.j@gmail.com
} 


\section{Az élet értelme: kultúránk válaszai}

A korábbiakban idézett Hankiss arra is rámutat, hogy valaminek célját, értelmét csak egy nagyobb távlatba, tágabb keretbe helyezve lehet meghatározni. Erre érez rá Arany János jól ismert rövidversében, a Sejtelem címü, 1882. március 2-i epigrammában.

Sejtelem

Életem hatvanhatodik évébe'

Köt engemet a jó Isten kévébe,

Betakarít régi rakott csürébe,

Vet helyemre más gabonát cserébe. [2]

Sejtelem: igen, a közelgő halál elöérzete, intézzük el egy legyintéssel a szöveget. És talán észre sem vesszük, hogy a vers alapvető metaforája (én = gabona) hogyan tölti fel mély, filozófiai tartalommal ezt a négy kis sort. Mert a metafora szerint a „jó Isten” okos gazdaként bánik a gabonájával. Elveti, időben learatja, „,betakarítja”, elhelyezi a jó előre megépített „csűrbe”. És bár a szövegszinten erröl nincsen szó, mindebböl következik az is, hogy a „jó Isten” éppoly céltudatosan bánik a maga gabonájával (az emberrel), mint a jó gazda. Ebből a tágabb nézőpontból már egyértelmü, hogy az ember nem látja, nem ismerheti ezt a célt, ahogy a gabona se ismerheti a maga létének célját, értelmét. Ez már „a nem ismert tartomány, / Melyből nem tér meg utazó” - ahogy Hamlet fogalmaz. [3] A gazda dolga, kötelessége, hogy ezt a célt ismerve járjon el. Talán az emberi élet célja, értelme is ott van valahol az „aratás”, a halál után. Jó volna ezt tudni, mondja a vers. De ez csak „sejtelem” lehet az ember számára, sőt ehhez a sejtelemhez is az Isten létébe vetett hitre van szükség. És így már egészen más jelentést, távlatot kap a cím, a „Sejtelem” is. Már csak egy lépés Einstein híres mondása: "Az egyetlen érthetetlen a Világegyetemben az, hogy érthető." [4]

Az emberi lét értelmének megértését (vagy legalább is értelmének ismeretlenségét) az elmúlt kétezer évben segített elfogadni a zsidó-keresztény hagyomány, amely a történelmet, s benne az egyén életét is egy elöre haladó üdvtörténet részének tekintette. S bár Európa a XVIII. század óta szekularizálódik, a folyamatos fejlődés, emelkedés képzetét a felvilágosodás is átvette, s ezt tetőzte be a hegeli filozófia, melyet ebben az értelemben a XX. század közepéig semmi sem haladt meg.

Talán nem véletlen, hogy két időben annyira távoli költő, mint Madách Imre és József Attila, az emberi lét értelmét egyként az etikaiban, az önmagáért vállalt etikus magatartásban vélte megtalálni. Madách így ír Az ember tragédiája 15. színében:

Az Úr:

Ha látnád, a földön múlékonyan

Pihen csak lelked s túl örök idő vár:

Erény nem volna itt szenvedni többé.

Ha látnád, a por lelkedet felissza:

Mi sarkantyúzna nagy eszmék miatt,

Hogy a múló perc élvéröl lemondj?

Míg most, jövőd ködön csillogva át,

Ha percnyi léted súlyától legörnyedsz,

Emel majd a végetlen érzete.

S ha ennek eltagadna büszkesége,

Fog korlátozni az arasznyi lét.

s biztositva áll nagyság, erény. - [5]

József Attila pedig ezzel a kétsoros epigrammával fogalmazza meg az emberi élet etikai lényegét:

Mért legyek én tisztességes? Kiterítenek úgyis!

Mért ne legyek tisztességes! Kiterítenek úgyis. [6]

Csak a XX. század borzalmas tapasztalatai, a soá és Hirosima után vált végleg kétségessé, hogy van haladás, fejlődés a történelemben, $s$ innen már csak egy lépés volt, hogy Fukuyama kimondja, a két nagy diktatúra bukása után itt a „történelem vége”, megállt az idő. S bár gondolatát sokan vitatták, vitatják, a közgondolkodásba is átszivárgott, hogy nincs többé sem transzcendens, sem immanens cél az emberi történelemben, s ezzel az egyén életében sincs. Ez adja a hátterét annak a posztmodern életformának, amelynek talán legtipikusabb megjelenései a bevásárlóközpont céltalan csellengője, vagy az internet virtualitásába bújó játékos. 
Mindennél inkább szükség mutatkozik tehát a tündérmesék legföbb üzeneteinek újra felfedezése, megértése iránt. Hogy melyek ezek, arról 2018-ban megjelent kötetemben próbáltam számot adni. [7]

Úgy vélem, a tündérmesékben egy olyan, ma is érvényes, kultúrákon átívelő, semmiféle külső, transzcendens megerősítésre nem szoruló etikai rendszer jelenik meg, amely az ember legalapvetőbb tulajdonságára, az empátia velünk született szükségére és képességére épül. Első helyen a tündérmesékben mindig az emberi élet tisztelete és az empátia áll. Minden további erkölcsi tulajdonság bizonyos mértékig összefügg ezekkel vagy közvetlenül/közvetve ezeken alapul. Ilyen erkölcsi tulajdonságok alkotják a tündérmesék erkölcsi rendszerét (természetesen mindig ellenpárjaikkal együtt): segítőkészség, együttmüködés képessége, szeretet, kötelességtudat, hüség, illemtudás, eltökéltség, bátorság, kitartás, öszinteség, leleményesség, öregek tisztelete, tolerancia, a másik ember tisztelete. Mivel az ember empátiával születik, a tündérmesék erkölcsi világképe könnyen el- és befogadható számára.

A kötetben elsősorban ennek kifejtése állt szándékomban. Így viszonylag kevesebb szó esett tündérmesék másik, ma talán még aktuálisabb üzenetéröl: arról, hogy célt, értelmet visz az emberi létezésbe. Erre pedig talán sosem volt nagyobb szüksége a fiataloknak, mint manapság, amikor a tér kitágulása folytán a korábbinál talán sokkal hosszasabban és sokkal eredménytelenebbül keresnek maguknak identitást, célt, értelmet a létezésben.

Egy percre visszatérve az Arany-szösszenethez: vajon mit tarthat élete céljának, értelmének a gabona? Nyilván azt, hogy kiteljesítse a magban adott lehetöségeket, hogy nagyra nőjön, hogy élvezze a napfényt, az esőt, hogy bő termést hozzon (feltéve, hogy a metafora alapján a gabonát is felruházzuk értelemmel, érzelmekkel, céltudattal). Amihez így gondolkodva eljuthatunk, az valójában Horatius híres gondolata, a „carpe diem”. Hiszen mindannyian megszületünk, felnövünk, élünk, megöregszünk, s végül meghalunk, a két végpont között sok minden történik velünk. Ám egy lényeges választáson múlik, hogy mindezt átéljük, vagy megéljük. Azaz üres, értelmetlen csellengéssel, a végtelennek tünő idő úgy, ahogy történő eltöltésével múlasztjuk életünket, vagy éppen értelmes tartalmakkal, élményekkel töltjük meg.

Így már közel járunk fő kérdésünkhöz: mi is az élet értelme? Hankiss Elemér $A$ Nincsböl a Van felé címü könyvében végigtekint az emberiség által eddig adott válaszokon, de egyértelmü, általánosan elfogadhatót nem talál. [8] „Az én számomra azok a legrokonszenvesebb válaszok [...], amelyek azt a meggyőződést fejtik ki, hogy az élet értelme magában "az élet értelmének keresésében « rejlik." - írja máshol. [9]

Mondhat-e akkor erröl bármit az irodalom? Hiszen az csupán fikció. Szabó Edit így ír erröl: „Az irodalom segítségünkre van abban, hogy mentálisan közelítsünk mások élményvilágához. [...] Suiyama ezzel összhangban azt állítja, hogy az elképzelt világokban való »részvételünk« is az információszerzés egy formája: ha eljátsszuk hogy a szarvast üldözzük, vagy elképzeljük, ahogyan más valaki üldözi a szarvast, azáltal olyan információkat és/vagy képességeket sajátítunk el, amelyek segítenek, hogy a valóságban majd elkaphassuk a szarvast. [...] Mellmann magyarázata szerint a valódi és a virtuális tapasztalat között csak racionálisan tudunk különbséget tenni, érzelmileg nem, vagyis az érzelmi válaszunk az inger valóságosságától függetlenül létrejön." [10]

Elmondható tehát, hogy a tündérmesék (amelyeknek morfológiájával Propp foglalkozott [11]) az emberi életnek azokat a legfontosabb mozzanatait jelenítik meg a lehető legáltalánosabb szinten, amelyekkel valamennyien találkozunk.

Egyúttal elültetik ezeket a tudattalan „én”-be, amely később érzelmi hatással is döntően befolyásolja döntéseinket. Ezt Timothy D. Wilson így fogalmazza meg: „a tudattalan.[...] egy olyan mentális folyamat, amely hozzáférhetetlen a tudat számára, de amely befolyással van ítéleteinkre, érzéseinkre vagy magatartásunkra." [12]

Hogy ezeknek az érzelmeknek milyen jelentős a hatása személyiségünkre, talán felesleges is bizonygatni. Heller Ágnes írja: „Az ember partikuláris adottságokkal születik, partikuláris nézőpontja transzcendálhatatlan. Az ösztönvezetés funkcióját - az embernél - primeren a társadalmi szokásrendszerek veszik át. Ezért azt mondhatnánk, hogy a partikuláris és individuális magatartástípusok közül a partikuláris a »természetesebb«. Ezzel szemben az individuális magatartás a »második kilépés « a természetből.” [13] Illetve: „Az individuális viszony, azaz az értékek választása, distancia önmagunkkal és környezetünk szokásnormáival szemben e választott értékek alapján nem más, mint tudatos viszony a nembeliséghez. Ez a tudatos viszony a 
nembeliséghez, mint választott viszony, tartalmazza a szabadság mozzanatát és mint szabadság és tudatosság, a nembeli lényeg konstituensei." [14]

Ha áttekintjük a tündérmesék szerkezetét, azonnal láthatóvá válik, hogy a mesehős útjának (életútjának) van célja, értelme. Ez leegyszerüsítve úgy fogalmazható meg, hogy felnőtt, a világot megismerni akaró, a boldogságot kereső emberré kell válnia.

A már többször idézett Hankiss Elemér az emberi élet értelmére, céljára kérdezve többek között Jungra hivatkozik. „Carl G. Jung tágabb keretben mond valami hasonlót: »Létem értelme az, hogy az élet egy kérdést tett fel nekem. Vagy megfordítva, én magam vagyok a kérdés, amely feltétetett s világnak, és nekem magamnak kell megtalálnom és elmondanom a választ, mert ha nem teszem meg, akkor a világ válaszától válok függővé." Ami azt jelenti, hogy elvesztem a szabadságomat." [15]

Vagyis: az ember dolga, létének értelme, tartalma, hogy megtalálja önmagát, hogy válaszolni tudjon arra a kérdésre: Ki vagyok én?

Ha így tekintünk a tündérmese szerkezeti egységeire, láthatjuk, erröl van szó a mesékben. $A z$ útnak induló, hétköznapi mesehős tulajdonságai fokozatosan bontakoznak ki elöttünk, s miközben saját útját, célját keresi ebben és a másik világban, egyre inkább megtalálja önmagát.

Az adaptív tudattalan igen korán alakul ki, részben genetikailag meghatározottan, a tudatos én kialakulása viszont három-négy éves kortól kezdődő, hosszú-hosszú folyamat. A tündérmesék cselekménymozzanatai éppen ezt a tudatosodást, egyúttal a partikulárisból való kilépést, az élet megélését ábrázolják és segítik elő.

\section{A tündérmesék nézőpontja: útkereső hősök}

A károkozás, a kiinduló helyzet megváltozása még tölünk független: senki sem dönthet saját megszületéséről, de születésével azonnal felborítja a fennálló rendet, a család kialakult egyensúlyát. A házaspárból szülők válnak, életük végéig tartóan apa és anya lesz belölük. Ha már volt egy gyermekük, az addigi egykéböl testvér lesz (báty vagy nővér). A második gyerek egyszerre középsővé válik, és az újszülött lesz a legkisebbé.

Az útnak indulás következik. Hiszen mire nagyjából kialakulna az új rend, addigra az új jövevényt külső és belső késztetések kilendítik a családi körből, mert akár tudatosul benne, akár nem, világa tágul, óvodás, iskolás lesz, új kapcsolatai, új igényei jönnek létre. Néhány jellegzetes példa ezzel a problémakörrel kapcsolatban a mesékböl:

„-Eredj, nézd meg azt az Ibolyát, ha szereted, vedd el. Ismerem az apját, jó ember." [16]

„Kedve támadt egyszer egy szegény székely legénynek, hogy megházasodjék.” [17]

„Egyszer, mikor a gyerek már megnőtt s megokosodott, azt mondta:

- Édesapám, jó volna valahova elmennem, szolgálatot keresni." [18]

„Fiaim, ha ti a fiatalságnak meg a halálnak vizéböl tudnátok többet nekem hozni, s megkerítenétek az aranyszóló pintyőkét, megfelezném veletek a birodalmamat." [19]

„Azt mondja egyszer a fiú az anyjának, hogy ö bizony nem sanyarog többet itthon, elmegy szerencsepróbálni.”[20]

Itt térbeli helyváltoztatás következik. A hősnek ki kell lépnie komfortzónájából, el kell indulnia saját útján, el kell jutnia az erdőbe (a való világba, az élet sürüjébe). Ennek során gyakran ér válaszúthoz, ahol döntenie kell, emellett sokszor akadályba ütközik, melyet le kell győznie, vagy problémába, melyet meg kell oldania, hogy továbbhaladhasson. Mint ahogy már az eddigiek során, itt is olyan sokféle élethelyzet jelenhet meg, amely átfogja szinte az élet teljességét. Néhány példa:

„Zöldszemü Péter [...] nekieredt az ádáz sötétségnek. Ment, mendegélt, annyi sötétséget hagyott maga mögött, hogy ezer éjszakára elegendő lett volna, mégsem jutott a végére. $A$ hetvenhetedik napon elérkezett a gonosz vén táltos házához." [21]

***

„A legkisebb királyfi ezenközben nyugatnak hajtotta a lovát. Harminchárom országot hagyott maga mögött, s még mindig nem talált rá a nyílra. Mikor aztán se várost, se falut, de még csak egy 
kunyhót sem látott, megijedt. Visszafordult volna minden bizonnyal, ha nem fél az apjától, aki meghagyta volt, hogy a nyil nélkül meg ne térjen. Tovább ment hát nagy búsan, s szidta magát, hogy miért pattintotta meg oly erősen az iját. Egyszer csak egy nagy barlangerdőbe ért. Olyan sötét volt, hogy alig látott, s untalan beleütközött a fákba." [22]

„Mennek, mendegélnek. Ha hegy akadt az útjukba, könnyen segítettek rajta, mert Hegyhengergető koma egyszerüen félretolta. Ha pedig nagy folyó akadt az útjukba, azon meg Fanyüvő koma segített azzal, hogy kihúzott egy nagy fát a földböl, átdobta a vízen, és mint hídon, azon átmentek."[23]

***

„No! Szegény kislány hova forduljon most már? El van csapva azért az egy szóért. Szegény lánynak, mit volt mit tenni: összeszedte, ami kis holmija volt, azzal elindult világnak.

Megy, mendegél, maga sem tudja, merre, nagy sokára egy nagy gazdaságra talál, amiröl azt se tudja, hogy kié. Kérdezösködött itt is, ott is, úgy hallotta meg, hogy egy nagyon gazdag királyé.

Akkor elöadta, hogy mi járatban van, kiféle, miféle. Hogy ő szolgálatot jött volna keresni, ha találna." [24]

A következő mesemozzanat, a találkozás a segítővel, adományozóval nem egyszeri esemény az életben. De ahogy halad az ember, keresve saját útját az erdőben, egyre gyakrabban kell döntenie, választania, egyre nagyobb tudatosságra van szüksége. $S$ ha az útnak indulásnál talán még nem fogta ezt föl, itt már nyugodtan támaszkodhat a tündérmesék üzenetére, hogy ne elbukó álhős, elsodort mellékszereplö, hanem föhős legyen saját életében.

Ez az a pont, ahol a hős empatikus magatartását teszi próbára a mesei történet. Itt hangzik el oly gyakran a ,jó tett helyébe jót várj" fordulat. Ez semmiképpen nem valami üzleti ajánlat, hiszen a kisegített lény gyakran nem jelenik meg ismét a történet során. Még az adományozók esetében is, amikor konkrétan ad valamit a megsegített, szépen köszöntött szereplö, akkor is legtöbbször olyan varázstárgyról van szó, amelynek haszna csak jóval késöbb derül ki.

Valójában tehát valamiképpen a kölcsönös segítségnyújtásról van szó. Arról, hogy a feláldozott érték (elemózsia, erőfeszítés) hosszabb távon megtérül, sőt akár többletet is hozhat. Erröl ezt mondja az evolúciós pszichológia: "elönyös lehet az együttmüködés olyan élölényeknél, beleértve az embert is, melyek csoportban élnek, és rendszeres idöközökben találkoznak egymással, a gyakori találkozással pedig nő a megtérülés esélye is. Tehát összességében a csoport tagjai élvezhetik, hogy időröl időre kisegítik őket, ami hosszú távon kimondottan nyereséges lehet." [25]

Azaz a tündérmesék alapvető túlélési tanácsot adnak hallgatóiknak, olvasóiknak. Ez, amit proszociális viselkedésnek szokás nevezni, különösen világosan megmutatkozhatott a zárt, falusi közösségekben, de valójában érvényes ma is, tágabb, de valamiképpen mégis összetartozó közösségekben (pl. osztálytársak, autósok, túrázók, vásárlók, stb.). Itt szívesen hivatkoznék a kommunikációs képességre, mint a varázseszköz vagy a segítő elnyerésének feltételére.

Ugyanakkor érdemes figyelembe venni Boldizsár lldikó véleményét, aki így ír erröl: „A mese szerkezeti csúcspontja az a pillanat, amikor a hős kapcsolatba kerül a segítővel, akár úgy, hogy találkozik vele, akár úgy, hogy a segítö a birtokába kerül. Attól kezdve eltökélten követi célját, és valóban olybá tünhet, mintha mindent a segítő végezne el helyette. Propp - aki kifejezetten morfológiai szempontból vizsgálta a meséket - nagyon találóan jegyzi meg, hogy ez azért van így, mert a segítőtárs nem más, mint a hős képességeinek megszemélyesítője, azaz - és ez a kijelentés a morfológiából a meseterápiába vezet át - a hős és a segítő funkcionálisan azonos személyek." [26]

Mire eddig eljut, a mesehős már jócskán benn jár az erdőben. Talán utat is vesztett, $s$ az adományozó éppen a cél felé vezető információval ajándékozta meg.

Nézzünk a segítőkre is néhány példát:

"- Na te legény - mondá -, megöregedtem, kenyeremnek javát megettem, de még ilyen szolgám nem volt. Neked igértem, neked is adom az aranyszörü bárányt, legyen rajta szerencséd." [27]

„Amikor Palkó kioldozta a gyík lábát, amaz megszólalt: 
- Köszönöm, Kicsi Palkó, hogy részvéttel voltál hozzám. Jótettedért jót várj. Tedd el az aranyfonalat, amit a lábamról leoldottál, még hasznát veszed." [28]

„- Ne ölj meg, te szegény ember, mert egész életedre boldoggá teszlek, ha meghagyod az életemet.

- Ugyan, mit beszélsz, te kígyófiú - mondá a szegény ember -, nem vagyok én olyan bugyuta bolond, hogy higgyek a te ígéretednek.

- Már bizony csak higgy nekem, szegény ember, s nem bánod meg. Nesze, adok neked egy acélgyürüt, húzd fel az ujjadra...” [29]

„Amint ott eddegélne, csak eleibe fut az egérke, s igen szépen kéri, hogy adjon neki Isten nevében egy falás pogácsát, mert éppen tizennégy álló nap, hogy nem evett.

- Jó szívvel - mondá a legény -, te kicsi egérke, úgyis talán megsegít a jó Isten, hogy nem kell ebböl a pogácsából sokáig élnem. [...]

- Ezt a kürtöt neked adom - mondá az egérke -, tedd el, még hasznát veheted." [30]

„Kérdi a királyfi:

- Hát te ki vagy s mi vagy? mi a mesterséged?

Mondja a széles mellü ember:

- Én Fúvó vagyok, s egy fuvintásomra a legnagyobb ház is összedől s a legnagyobb fákat is pozdorjává töröm.

- Ejnye-mondja a királyfi -, éppen nekünk való ember vagy, állj közénk kenyeres pajtásnak."

De akárhogyan is, ekkor jön el a pillanat, egy újabb térbeli helyváltoztatásé, amikor a hősnek át kell lépnie egy másik (felső? alsó? titkos?) világba. Ehhez bátorságra és eltökéltségre van szüksége. S ez a mozzanat is valamennyiünknek szól: ha célt akarunk érni, el kell hagynunk a látszólagos biztonságot adó hiteinket és előítéleteinket. Igaz, itt egy elsőre félelmetesnek tünő, ismeretlen, kockázatos világba jutunk, ám aztán szinte mindig kiderül, valójában ez ugyanolyan világ, mint ahonnan jöttünk, talán csak a mesehős változott meg:

„Nekifohászkodott, behunyta a szemét - szervusz világ! - ráugrott a falevélre, hogy csak elterült rajta, mint egy kecskebéka. No, csakhogy itt van!

Bezzeg elállt szeme-szája, mikor széjjelnézett. Hát itt éppen olyan ország van, amilyen odale."

\section{$[\ldots]$}

„Az ám, éppen a föld kellős közepéig. Itt volt a lik, amelyiken le lehetett menni az alsóvilágba.

Ment, mendegélt Pali az alsóvilágban, s estefelé meglátott egy asszonyt, amint éppen vizet merített a kútból. Nézi, nézi, hát ez az asszony csudálatosan hasonlít az ő anyjához." [33]

Ekkor a hős már viszonylag gyorsan szemben találja magát az ellenféllel, a gonosszal. Igen gyakran már a "másik világ” határán feltűnnek sárkányok, melyeknek éppen a határ őrzése a feladatuk. Kútnál, hídnál, stb. állnak, mert az élet és a halál birodalmát szinte mindig víz választja el, amely lehet az élet vagy a halál (netán a csodás újjászületés, átváltozás) vize.

„Hajtani kezdte a legény a nyájat, a nyájban az aranyszőrü bárányt. Hajtotta, hajtotta, egészen az ezüsterdő hídjáig.

Mikor a hídon is átmentek, kibukott a sürüböl a tizenkét fejü sárkány, és se szó, se beszéd okádni kezdte a tüzet a legényre. Olyan komiszul, hogy a subája megpörkölődött.

- Megállj, megállj, te tizenkét fejü sárkány, mindjárt megbosszantalak a furulyámmal! - mondta a legény.”[34]

„A rét közepén pedig volt egy forrás, a forrás mellett egy rézvályú. [...]

Hát - Uram Jézus Krisztus, adj egy kicsi spirituszt! - alighogy az idősebb királyfiknak bekoppant a szemük, jött a hétfejü sárkány, s a hét szájából szaladt a láng hét röffel elöre.

- Gyere csak, gyere - mondá a kicsi királyfi -, emberedre találsz! Hej, hogy megküzdöttek, hogy megerösködtek, de hogy! Még a föld is rengett belé ahogy össze-összecsaptak, de a kicsi királyfi bizony nem költötte fel a bátyjait. Meggyőzte ő egymaga is a hétfejü sárkányt." [35] 
Míg ezek a sárkányok viszonylag könnyen (pl. csellel) legyőzhetök, az igazi gonosz, az ellenfél a „másik világ”-ban várja a host. Sokszor vendégként, sógorként, ismerősként fogadja a mesehőst, mintha eredendően volna valami a hösben, ami éppen ezt az ellenfelet hívjaa életre, éppen ennek az ellenfélnek a legyőzését kívánja meg.

Legtöbbször a hős és az ellenfél küzdelme eleinte kilátástalannak tünik. Hiába vágja földbe a hős ellenfelét térdig, mert az kiugrik, és most ő vágja a földbe a höst derékig. Vagy éppen (mint sok mesében) a gonosz elöször le is győzi, megöli a höst (akár apró darabokra is vágja), és csak valamely segítőnek köszönhető (pl. táltos paripának, leányfejü kígyónak), hogy a hős újra és újra feltámad, és csak miután egyre jobban megerösödve, megszépülve újjászületik, lesz végül képes felülkerekedni a gonoszon.

„Kettőt-hármat sem lépett, elejébe áll az óriás, s nagyot kiált: birkózol.

- Állj meg, hé! Innét tovább nem mégy, míg nem jössz velem az ólomszérüre, s ott meg nem

- Jól van - mondta a fiú - csak menjünk, ha meguntad az életedet.

Kimennek az ólomszérüre, ott megfogja az óriás, felkapja a fiút, s úgy levágja, hogy bokáig süppedett a szérübe. [...]

De a fiú is kiugrott, nekifohászkodik, fölkapja az óriást, s nyakig vágja a szérübe.

- No most gyere ki, ha tudsz!

Bezzeg, hogy nem tudott kijönni. Vette a fiú a kardját s lenyisszantotta az óriás fejét.”[36] ***

„A sárkány nagyot szisszent.

Ejnye, sógor, de kemény a kezed!

- Hát -feleli Fanyűvő -, így szoktam odahaza parolázni, sógorkám!

- No gyere - feleli a sárkány -, együnk egy kicsit elöbb, mert éhes vagyok! Azután megbirkózunk. Amelyikünk erösebb, az lesz a győztes. [...]

Harmadszorra Fanyüvő úgy vágta a sárkányt a földbe, hogy csak a fejei voltak ki. Azzal kapta a fejszét, és a sárkány minden fejét levágta, a nyelveket pedig a tarisznyájába rakta." [37] ***

„Megkeresték Rózsát, megfogták, összeaprították. mint a torzsát, és kihányták az ablakon.

Reggel az óriások megint elmentek keresetre.

Akkor a bokorból előmászott egy szép, leányfejü kígyó, és Rózsa testének minden kicsi darabját összeszedte, összerakogatta. [...] Egy közel való forrásból élö-haló vizet hozott, avval is meglocsolta.

Rózsa egyszer csak talpra szökött. Hétszerte szebb és erősebb lett, mint azelött." [38]

A gonosz legyőzése, a nehéz feladat megoldása egyúttal a keresett tárgy, személy megtalálását, megszabadítását is jelenti, és már csak a lakodalom, a hétköznapi felnőtt világba való belépés marad hátra. Mire idáig elér, a főszereplö, aki a mese elején hétköznapi ember volt (legkisebb királyfi, szegény legény), igazi hőssé válik. Ehhez azonban sokszor még egy utolsó csodára, valamiféle csodás átváltozásra is szükség van:

„-Ne félj tölem, szépséges szép királykisasszony! Nem vagyok én sárga kicsi kígyó, én egy elátkozott királyfi vagyok. Apám arra átkozott, hogy hét esztendeig, hét hétig és hét napig kígyóbörben járjak." [39]

***

„Telemeríti a süvegét a királyfi, aztán szépen felhasitja a nádszálat, nehogy megsértse a világszép Nádszál kisasszony gyönge testét, s ím csak kipattan a nádszálból egy olyan szépséges szép leány, amilyent még emberi szem nem látott. Ott mindjárt egymás nyakába borultak.

- Te az enyém, én a tied, ásó, kapa s nagyharang válasszon el minket!" [40]

$\star * \star$

„Akkor az ezüstmedve megrázkódott egyszer, s mindjárt Tüzmadár lett belöle. Megrázkódott még egyszer, s gyönyörü szép leány lett belöle.

- Meg ne rázkódjál még egyszer! - kiáltott rá Bátor Ákos. - Ennél szebb úgysem lehetnél.

Nem is rázkódott meg a gyönyörü szép leány, hanem a nyakába borult Bátor Ákosnak. El sem eresztette, míg a pap össze nem eskette öket" [41] 
„Akkor a kép mellöl lepattant egy szép veres huszár, kezében karddal. Kardjával levágta a kakas nyakát, s így lett vége Ej Hajnak.

Azt mondja akkor a huszár a királykisasszonynak:

- Mondd meg nekem most már, leszel-e a feleségem vagy nem?

- Leszek, ha édesapám is megengedi." [42]

***

„Estére kelve Disznófickó keresztülbütyközött a fején, s lett belöle egy tiszta gyémánt királyúrfi. A varas disznóbőrt, amiböl kibújt, odaakasztotta az ágy gombjára.

- Szívemnek szerelme, szívemnek kegyese, szeress engem - mondta a feleségének." [43]

***

„De erösködik a gyíkocska:

- Mondom, csak vágj engem oda a köhídhoz!

A királyfi váltig ellenkezett, de amikor látta, hogy a gyíkocska mennyire elszontyolodott, bekumta, vagyis jól behunyta a szemét, és úgy vágta a gyíkocskát oda a kőhídhoz. Hát erre mit lát? Egy gyönyörü szép fehérnépet a gyíkocska helyett. Azt mondja a szép lány:

- No, királyfi, rám ismersz-e?' [44]

Ugyanilyen gyakori, amikor a másik világból érkező hős (hősnő) a két világ határán (ismét víz mellett) kénytelen átváltozni:

„Azt mondja a tündérlány a királyfinak:

- Tisztelt kedvesem, sajnálom fáradságodat, de én ebben a tündérruhában nem vagyok bátor bemenni a te kastélyodba. Hagyjál itt engemet a kis nyúllal. Menjél elöbb csak te haza, hozzál nekem új ruhát." [45]

$* * *$

„- Édes szívem, szép szerelmem! Gyöngyharmat Jánosom! Látod, hogyan vagyok! Ha van lelked, add ki a ruhámat!

- Szárnyas ruha! Ha fölveszi, elszáll! Ki ne add!

Nem is akarta János odaadni.

A tündér csak rimánkodott, csak istenkedett tovább is, de János a ruhát nem adta oda.

- Nem adod ide, igazán? - kérdezte a tündér.

- Nem! - felelte János.

- Miért nem?

- Mert azt akarom, hogy az enyém légy!

Világi Szép Örzsébet elmosolyodott.

- Ezt vártam, János! Én sem akarok mást. Akkor adjál földi asszonynak való ruhát. Hogy az asszonyod lehessek?' [46]

Ez utóbbi szöveg egyértelmüen jelzi, hogy a másik (tündér) világból az emberibe való visszalépésröl van szó. [47]

Összefoglalva elmondható: a mesehös ezzel elérte, kiküzdötte, hogy a fele királyságot és a boldog szerelmet elnyerő királyfi/királykisasszony legyen belöle a saját életében.

\section{4. Összegzés}

A tündérmesék tehát egy olyan vándorlást, útkeresést mutatnak be, amely elvezetheti az olvasót a felismeréshez: neki is el kell indulnia, meg kell élnie, végig kell járnia saját élet-útját, felfedezve célját és értelmét. Más problémakörrel kapcsolatban fogalmazza meg Gábor György, de szavai tökéletesen illenek a tündérmesékre: „az aktív életigenlés révén válik az antik sorstragédiák valóságos szellemi ellentétévé. Itt ugyanis nem a fátum határozza meg az ember életének alakulását, s végzete nem a sorscsapások terhe alatti kegyetlen és elkerülhetetlen összeroppanás, hanem ellenkezőleg: annak tudatosítása, hogy a legnagobb katasztrófák, az elszaporodó gonoszság idején sem valamiféle kívülröl jövö csodában kell reménykednie, hanem önmagának kell sorsát alakítania." [46]

A tündérmesék alapvető jellemzője a csoda. De a csodáért a hősnek mindig döntenie, cselekednie kell, kockázatot kell vállalnia.

A hősnek el kell indulnia akkor is, ha két idősebb testvére már elvitte a jó lovakat, s neki csak egy járni sem képes, gondozatlan jószág marad: hiszen ez később csoda folytán táltossá válik majd. 
Vagy éppen le kell ereszkednie a föld alá, ahová társai nem képesek a félelemtöl: hiszen később kiderül, ott is olyan a világ, mint idefönt, csak ott csoda is kell a sárkányok legyözéséhez. Vagy el kell fogadnia, hogy az ő nyílvesszeje egy erdőbe esett, és ott nincs más menyasszonynak való, csak egy macskacicó, hát azt kell választania: hiszen később csodás átváltozás után kiderül, a macskacicó egy elvarázsolt királykisasszony.

Ezzel a lakodalom előtti-utáni átváltozásnak is megnyílik üzenete: ott és akkor mutatkozik meg végképpen a hős/hősnő valódi énje, személyiségének teljessége. Azaz megtalálja önmagát, identitása bizonyosságát. $S$ emlékezzünk, épp ez tünik a mai új generációk számára a lét egyik legnagyobb problémájának.

Ha feltárul a befogadó előtt ez az üzenet, maga is átérezheti, átélheti, hogy akkor találja meg élete célját, értelmét, ha odafigyel önmagára, ha nem tékozolja el az időt, a tehetségét, a keres és bejár feltáruló új utakat. Ha tudatosítja, hogy a hétköznapi feladatokban megtalálható önmaga kiteljesedésének, identitása kibontakoztatásának lehetősége. Ami egyúttal fontossá, tartalmassá is teszi számára a hétköznapok áradatát.

\section{Irodalomjegyzék}

[1] HaNKISs Elmér, Félelmek és szimbólumok, Bp., Osiris, 2006, 110.

[2] ARANY János, Költeményei, Bp., Helikon, 1983, 452.

[3] William Shakespeare, Hamlet, dán kiályfi, ford. ARANY János = ARANY János Összes müvei VII., szerk. KeRESzTURY Dezső, Bp. Akadémiai, 1961, 149.

[4] Idézi Paul DAVIES, Isten gondolatai, Bp., Kulturtrade, 1996, 143.

[5] MADÁCH Imre, Az ember tragédiája, kritikai kiadás, s.a.r. KERÉNYI Ferenc, Bp., Argumentum, 2015, 593.

[6] József Attila, Két hexameter = J. A., Minden verse és versfordítása, Bp., Szépirodalmi, 1980, 419.

[7] BÁRDOs József, A klasszikus tündérmesék korszerüsége, Bp., Pont, 2018.

[8] HankISs Elemér, A Nincsből a Van felé: Gondolatok az élet értelméröl, Bp. Osiris, 2012.

[9] Hankiss Elmér, Félelmek..., i. m., Bp., Osiris, 2006, 260.

[10] SzABó Edit, Narratívák evolúciós megközelítése = Evolúciós pszichológia mesterfokon, szerk. GYuRIS Petra, MESkó Norbert, Bp., Pannónia, 2016, 334-335.

[11] Vlagyimir J. Propp, A mese morfológiája, Bp., Gondolat, 1975.

[12] Timothy D. WILSON, Ismeretlen önmagunk, Bp., Háttér, 2010, 44-45.

[13] Heller Ágnes, Az érzelmek elmélete, Bp., Jószöveg Műhely, 2009, 190.

[14] Uo., 175.

[15] Hankiss Elmér, Félelmek..., i. m., Bp., Osiris, 2006, 260-261.

[16] Rózsa és Ibolya = ILLYÉs Gyula, Hetvenhét magyar népmese, Bp., Móra, 1979, 289.

[17] Az ördög kilenc kérdése = Uo., 404.

[18] Ej Haj= Uo., 415.

[19] Aranyszóló pintyőke = Uo., 130.

[20] Szép Palkó = BenEdek Elek, Magyar mese- és mondavilág, Bp., Könyvmíves, é.n., 22.

[21] Zöldszemü Péter = Kolozsvárı GrandPIERRE Emil, A csodafurulya, Bp., JLX, é.n., 92.

[22] A béka-királykisasszony = Uo., 187.

[23] Fanyüvő, Vasgyúró, Hegyhengergetö = ILLYÉs, i. m., 261.

[24] A libapásztorból lett királyné = Uo., 361.

[25] Evolúciós pszichológia..., i. m., 209.

[26] BoldizsÁr Ildikó, Meseterápia, Bp., Magvető, 2010, 155.

[27] Az aranyszörü bárány = BENEDEK, i. m., 30.

[28] Örömalma = KolozsváRI GRANDPIERRE, i. m., 269.

[29] Az acélgyürü = BENEDEK, i. m., 64.

[30] A király nyulai $=$ Uo., 66 .

[31] Szélike királykisasszony = Uo., 376.

[32] Az égig érő fa $=$ Uo., 10.

[33] Erős Pali = Uo., 238.

[34] A csodafurulya = KolozsvÁRI GRANDPIERRE, i. m., 2.

[35] A fekete havas = BENEDEK, i. m., 16.

[36] A zöld király = Uo., 321-322.

[37] Fanyüvő, Vasgyúró, Hegyhengergető = ILLYÉs, i. m., 274.

[38] Rózsa vitéz = Uo., 232.

[39] Sárga kicsi kígyó = BENEDEK, i. m., 200.

[40] Világszép Nádszál kisasszony = Uo., 350.

[41] Bátor Ákos = KolozsváRI GRANDPIERRE, i. m., 303-304.

[42] Ej Haj = ILLYÉs, i. m., 424.

[43] Disznófickó = Uo., 440.

[44] Ribike = ILLYÉs, i. m., 49. 
[45] A háromágú tölgyfa tündére = Uo., 551.

[46] Gyöngyharmat János = ILLYÉS, i. m., 499.

[47] Itt szeretnék emlékeztetni arra, amiröl már volt szó korábbi munkáimban, hogy a lányok épp ilyen nehéz próbák, alvilágjárás, feltámadás, átváltozás útján jutnak el a boldog felnőtté váláshoz. Csak emlékeztetőül utalok néhány magyar népmesére: Leányszín Bálint = KolozsvÁRI GrandPIERRE, i. m., 45., Szép Cerceruska = BenEDEK, i. m., 12., Az aranyhajú hercegkisasszony = ARANy László, Magyar népmesegyüjtemény, Bp., Franklin, é.n., 197.

[48] GÁBOR György, A személyes haragtól a kollektív gyülöletig = A történelem árnya, szerk. GÁBOR György, RugÁsı Gyula, Bp., Jószöveg, 2004, 119-149., idézet: 148. 